\title{
SMART HAPPY CITY
}

\author{
LAMIAA SHAHEEN \& MOHAMED ABDEL AAL IBRAHIM \\ Engineering Architecture Department, Alexandria University, Egypt
}

\begin{abstract}
Although people perceive architecture in a variety of ways, we firmly believe there are key elements of design that can enrich the human experience, facilitating a path towards human happiness and wellbeing. Through small changes, we can begin making the world a happier place, and architecture is definitely a tool to do so. The environment is essential for all of us, especially since so many of us live in cities; thus, the Egyptian Commission emphasized the value of cities in the lives of so many Alexandrians, by committing to take action in this area. Specific environments have a direct impact on the lives of millions of Alexandrian citizens, and as a result, have a significant impact on the larger environment. More change is required in Alexandria for it to be a Smart Happy City that should offer the kind of quality of life and opportunity that would make people want to live there, make businesses, and want to invest. The main goal is to make Alexandria a Smart Happy City by providing both a common ground and a common language for better understanding use of smart and happy features effectively, specifically to make Alexandria a Smart Happy City within the architecture realm. We explain smart city features, characteristics and happiness factors, and how happiness can be measured. Additionally, we provide examples of smart, happy features. Moreover, we consider what should make Alexandria a Smart Happy City, but as smart solutions cannot be fully reproduced, we evaluate the value of each field.

Keywords: Alexandria, old Alexandria, Smart City, Happy City, computer aided architectural design, architectural representation, computational design, happiness in communities.
\end{abstract}

\section{INTRODUCTION}

Alexandria is a four-season destination. In the winter you will enjoy the breezy mornings and cold nights, and you will also find a lot of rain if you're a winter lover. Something you need to know about Alexandria is that while summer makes perfect weather, we personally don't like it as much, as the crowds are overwhelming. Downtown Alexandria's wide waterfront road is as much a symbol of the city as any of its monuments. It's here that you get a real feel for the era of cosmopolitan elegance and decadence that marked this city, in the late 19th and early 20th centuries. Much of the architecture from this era still stands along the Corniche, though these days, much of it is heavily dilapidated and falling into disrepair. Alexandria faces problems too, in areas such as: chronic conditions, economic stability, health care access, injury, violence, mental health, neighborhoods, the built environment, obesity, nutrition, physical activity, oral health and reproductive health.

Our goal is to make Alexandria a Smart Happy City and to solve all of the abovementioned problems by following Smart City features implementation, which will lead to a happy community.

\section{ALEXANDRIA BEFORE AND AFTER}

Urban public spaces function to encourage public activity. Fig. 1 shows how the environment can influence the people. Issues like public spaces, air quality and greenness are actually having a big impact on our levels of happiness and wellbeing in our life [1].

A direct view towards the sea was blocked by cafes and concrete blocks, which has a very bad effect on users (Fig. 2). Therefore, quality of life (QOL) as measured by people's selfreported happiness is a primary goal of urban design. A high QOL tends to be a virtuous cycle that attracts greater economic activity and investment, leading to improved QOL. 


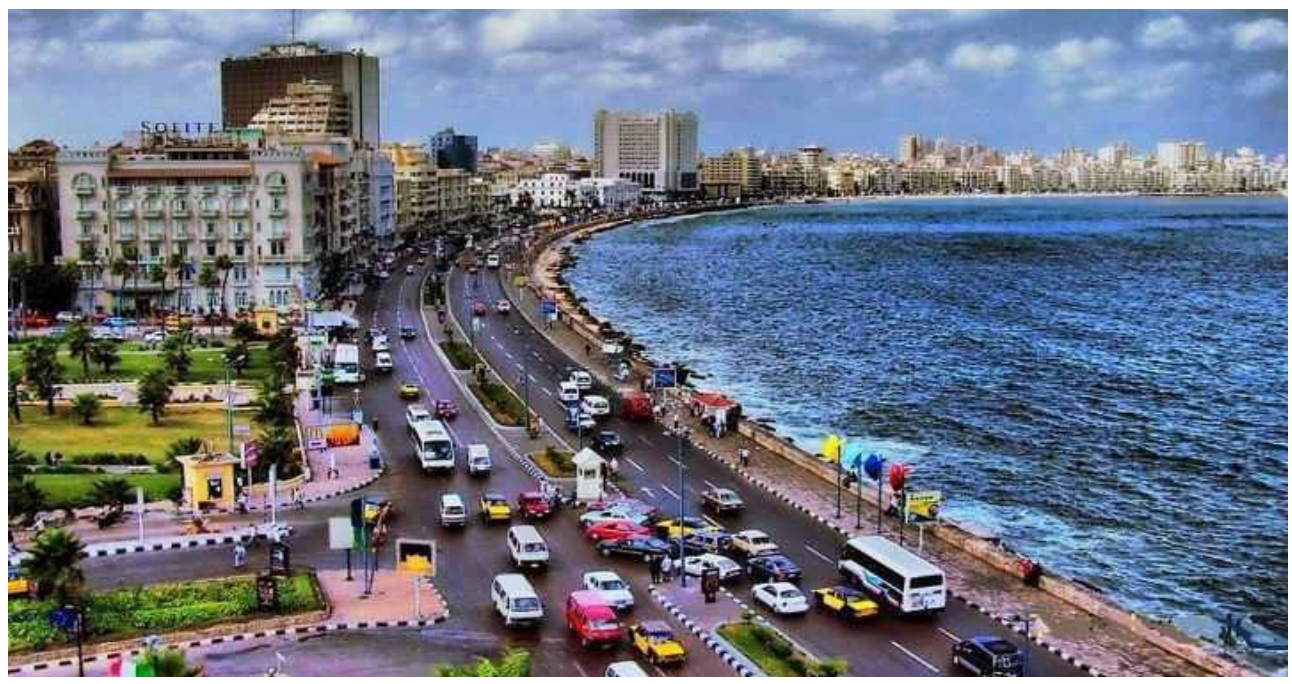

Figure 1: Mehatet el Raml area, 1990. (Source: https://www.planetware.com/touristattractions-/alexandria-egy-alex-alex.htm.)
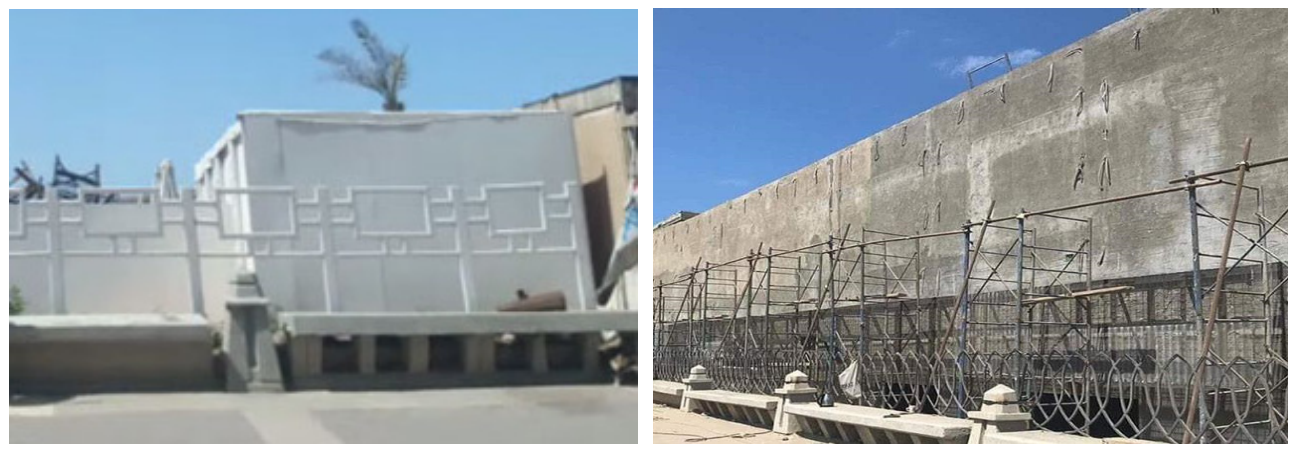

Figure 2: Mehatet el Raml area, 2021. (Source: https://www.planetware.com/touristattractions-/alexandria-egy-alex-alex.htm.)

The goal of CITYKeys was to develop and validate a performance measurement framework to promote common, transparent, and comparable tracking of Smart City solutions across many European cities. Indicators are included at two levels in the framework: city or neighborhood, and project. The former compares the before and after results of a Smart City project to assess its impact, while the latter compares the expected effect to a reference point. The latter also monitors the city's overall progress toward Smart City goals and evaluates how the project contributed to the city's goals [2]. The evaluation framework includes considerations for the three Ps (people for social sustainability, planet for environmental sustainability, and prosperity for economic sustainability), as well as governance and scalability/replicability (under the heading Propagation, in Fig. 3). For each of these five categories, correlating indicators were identified (Fig. 3). A Smart City approach to protection of the environment, for example, is evaluated using indicators such as efficiency 
and climate mitigation performance. From the start, cities and local governments were involved in the project, and the indicators were developed in collaboration with them. It necessarily required a multifaceted approach, devoting effort towards breaking down silos in urban project design and implementation [2].

\begin{tabular}{|l|}
\hline \multicolumn{1}{|c|}{ People } \\
\hline $\begin{array}{l}\text { Health and } \\
\text { safety }\end{array}$ \\
Access to \\
services \\
Education \\
Quality of \\
housing \\
Diversity and \\
social \\
cohesion
\end{tabular}
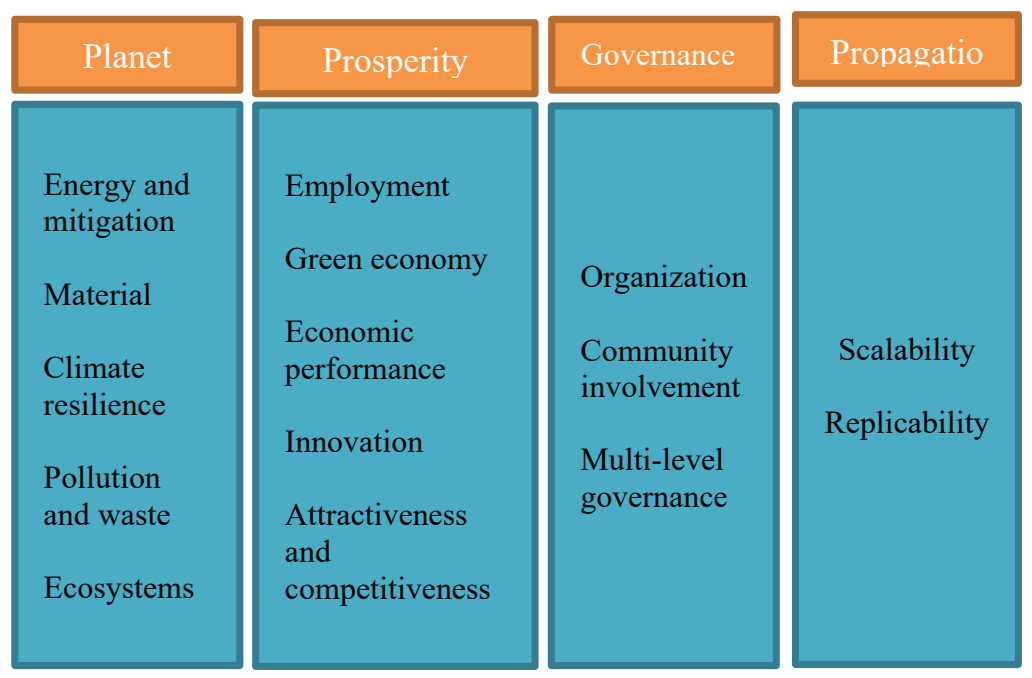

Figure 3: Five evaluation indicators categories of CITYKeys project. (Source: Authors, 2021.)

\section{CHARACTERISTICS OF A SMART CITY WHICH LEADS TO HAPPY CITY [3]} The "Smart City" concept can be reviewed within three dimensions: Technology, Human and Institutional (Fig. 4) [3].

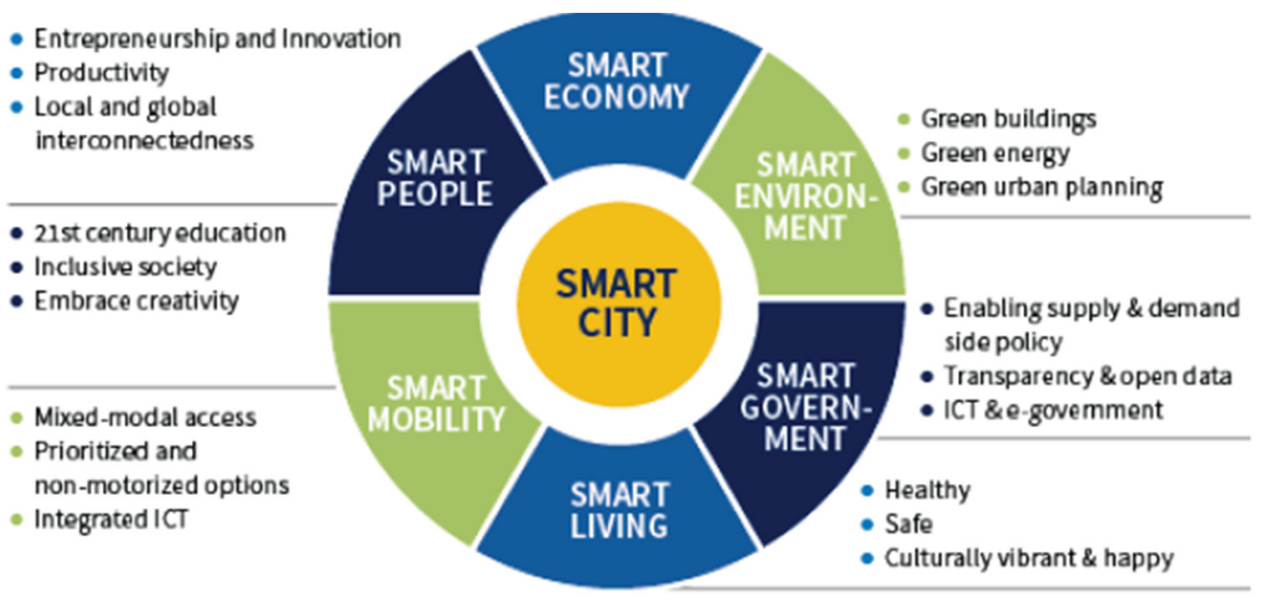

Figure 4: Characteristics of a Smart City. (Source: Authors, 2021.) 


\section{HAPPINESS-RELEVANT CIRCUMSTANTIAL FACTORS}

Many research studies focus on the how people affect the environment, but none are researching how the environment influences the people. Issues like waste management, air quality and greenhouse gas emissions are, actually, having a big impact on our citizen's levels of happiness and wellbeing in life.

\section{HAPPINESS-RELEVANT USER ACTIVITIES}

Urban public parks function as a theatre for encouraging public activity. The top image in Fig. 5 shows the Al khaledeen public park in 1990 and there is happiness in its design. The architect chooses to respect the nature of this by not removing any trees from the park. This design makes a gentle transition between the park, square and the historic neighborhood in Alexandria. The bottom image in Fig. 5 shows Al khaledeen public park after development: We notice that there are no green areas like before, it was transformed to a concrete building with cafes.
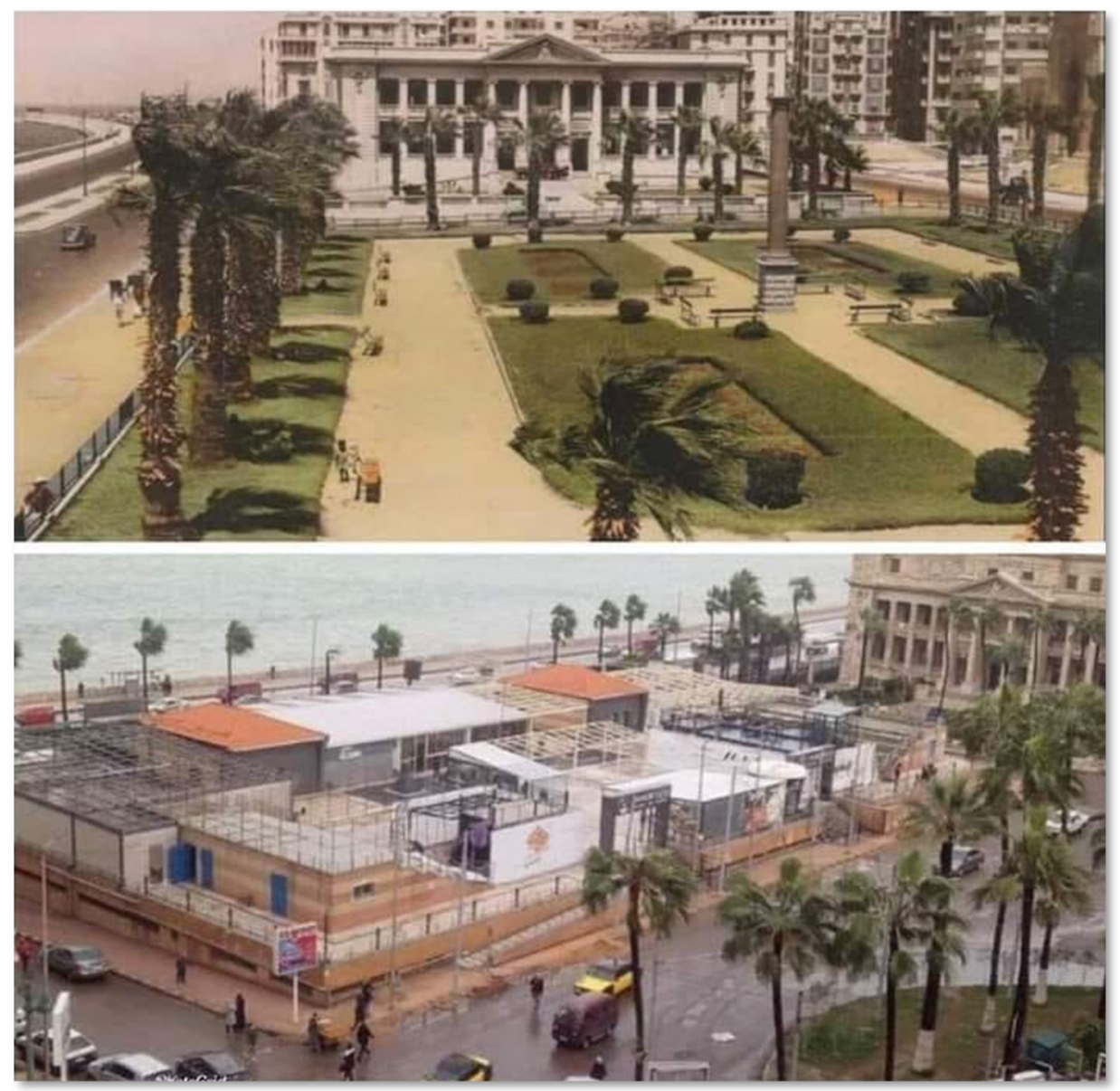

Figure 5: Al khaledeen public park. Top image shows the park before development in 1990; the bottom image shows the park after development, in 2021. (Source: www.facebook.com/AlexandriaCitizens/posts/3608311959296086/.) 


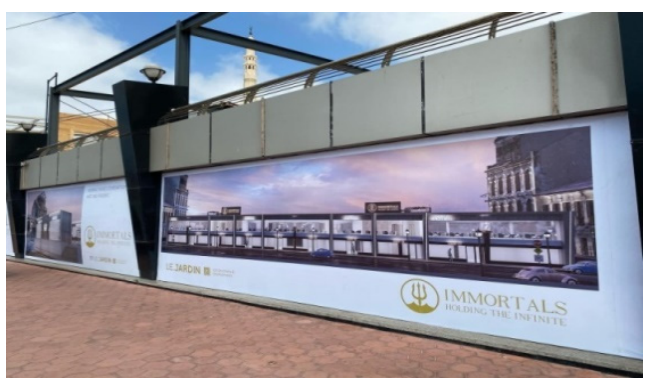

(a)

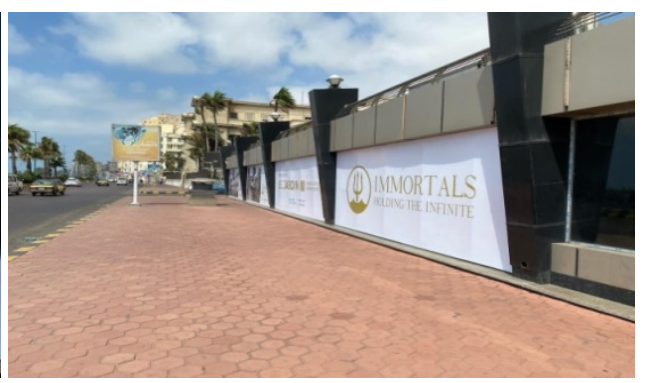

(b)

Figure 6: Al khaledeen public park elevation to the sea side 2021. (Source: https://arar.facebook.com/alexhabebti/posts/3280973638608074/.)

\section{HAPPINESS IN THE CITY}

Plato's statement that "the city is what it is because our citizens are what they are" serves as a good reminder of how important people are in any consideration of a city; thus, the wellbeing of people in the city is essential. This is especially important because cities are expected to house $75 \%$ of the world's population by 2050 . Such perspectives contrast with definitions that lack the spirit of a city, such as being "an urban geographical area with one (or more) local government and planning authorities" [4].

Gehl believes that urban planners should strive to create cities that are livable, safe, sustainable and healthy, emphasizing four characteristics. A walk should be useful, safe, comfortable and interesting to a citizen. Thus, walking is encouraged, increasing the likelihood of social interactions as people pass each other at walking pace, rather than speeding by within the physical barrier of cars [5].

The difference now is that, as digital technology becomes more widely available, it provides even more opportunities to improve one's QOL. The world is currently experiencing the fourth industrial revolution (4IR), in which technology is fusing the physical, digital and biological worlds, promising people even more value through city planning (physical, organizational, informational, etc.); which must therefore support the aforementioned benefits of a city. Technology may be used to enhance such support, potentially leading to a happier city [6].

\subsection{Feedback loop: Measures, tools and interventions}

At various levels of sophistication, any organization operates a feedback loop in which actions are based on some reasoning and insight extracted from data. This is the classic feedback loop where data for a Smart City (or otherwise) can be obtained from a variety of sources, including observation; surveys; and digital sources such as the Internet, database systems, even general knowledge. Processing and insight collection can be carried out manually, using rudimentary algorithms, or using artificial intelligence (AI). The solution could take several forms, including the immediate provision of personalized services or the modification of general service settings to improve efficiency. A Smart City with advanced feedback loops is also known as a conscientious and responsive city, using data-driven urbanism, which describes how cities are becoming increasingly instrumented and networked, their systems interconnected and merged, and where vast troves of data generated are used to manage urban life. Data-driven cities are becoming more common in the Fourth 
Industrial Revolution (4IR). Section 6 describes many analog and digital factors, also feedback loop examples, that civic leaders may use to realize the promise of hugely complex ways to interact with residents, not just by asking, but providing direct rebuttals to behavioral data as well, while creating an efficient city that works to deliver happiness [7].

6.2 Digital and analog aspects of the feedback loop (Fig. 7)

1. Measure: Gather behavioral data (e.g., telecommunications, retail data) and reported data (e.g., satisfaction scores).

2. Process: Analyzing data and input, then converting them into insights and recommendations (e.g., modeling and evaluation tools).

3. Respond: Act in response to insights, automatically or manually, based on set criteria (e.g., activities, interventions and policies).

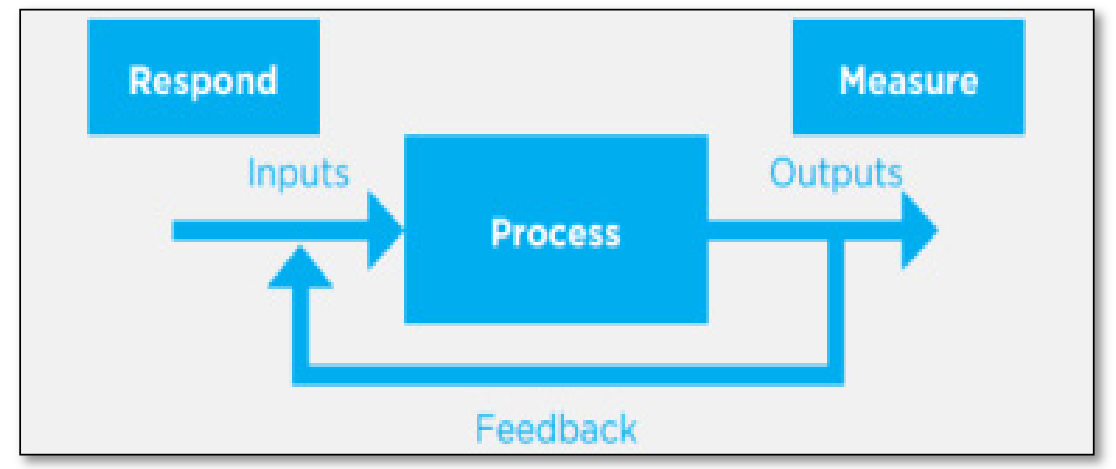

Figure 7: Digital and analog feedback loop [7].

\subsection{Case: SHAPE Tool (Dubai, United Arab Emirates (UAE))}

Dubai's technological journey began in 1998 with the declaration of its first information and communications technology (ICT) strategy, and has since been followed by the establishment of Dubai Internet City, Dubai e-government, Dubai Smart Government, and most recently, the Smart Dubai initiative, which was started up in 2014. Dubai's numerous digital transformation initiatives fuel public acceptance and adoption of ICTs in all aspects of life over the last two decades. Today, Dubai, a city of 2.5 million people and one of the seven Emirates of the UAE, has one of the highest levels of ICT adoption in the region. According to His Highness Sheikh Mohammad Bin Rashid Al Maktoum, vice-president and prime minister of the UAE and ruler of Dubai, technology, as a framework for solutions, is merely an enabler, rather than the primary goal. The Smart Dubai initiative is bringing to fruition His Highness' vision of making Dubai "the happiest city on the planet".

Dubai unveiled Smart Dubai 2021, a five-year strategy, in 2017. The new strategy explicitly shifts the strategic focus from enabling, to having a significant positive impact on the city through digital transformation.

The "Smart Happiness Index" (SHI) was developed in partnership with the Gallup Organization. Happiness is linked to the six elements of the Smart Dubai 2021 Strategy, via this compound index derived from quantitative data research: economics, people and society, 
governance, mobility, environment and living. Since then, the project moved on to the next stage, which is the development of a decision tool known as the Smart HAppiness Project Evaluation tool (the SHAPE tool considers different key performance indicators (KPIs) within the city plan's six pillars and provides weighting, based on the relationship between these KPIs and sample satisfaction, using data from over 4,300 Dubai residents as a representative sample (chosen from all segments of society, includes resident expats and citizens)).

When calculating the SHI index for each project, the program takes into account a number of other factors: One is adaptation, where the tool takes into account how long the benefits will last, as well as how quickly and to what extent people will adapt to new projects or service improvements. Finally, based on the cost of the project under consideration, the SHAPE tool computes a cost-effectiveness ratio. This ratio denotes the expected increase in happiness for each dirham that is spent. Users simply respond to a series of structured questions via a simple online interface, and the program computes the SHAPE score and the cost-effectiveness ratio, so they can then compare to other projects. Instead of being overly arbitrary, this gives the user a sense of the relative meaning of the figures. These findings can offer data-driven insight into how much their project contributes to a city's happiness vision, enabling project managers to fine-tune and improve their projects, thereby increasing their effectiveness. Use of the tool facilitates planning and decision-making procedures in both public and private sectors, by allowing organizations to tailor their projects for maximum durability and impact on happiness [8].

\section{ENVIRONMENT}

The quality of a city's natural environment has a significant impact on the happiness of its residents. This, on the other hand, has a direct local as well as a global impact. As a result, several environmental issues, including air quality, waste, sustainability, energy and water use must be addressed.

Some programs, such as Quito's carbon and water footprint calculator, contribute to the city's overall environmental KPIs. The goal is to raise public awareness of the city's environmental impact.

\subsection{Case: Goodwill Waste (Seoul, South Korea)}

City managers in Seoul's "Sharing City" faced the challenge of finding a workable balance between waste collection and disposal. The method proposed that a Volume-based Garbage Collection Fee (VGCF) replace the previous system, which was a property-based tax. The new system is based on the co-production principle, which is a collaboration between citizen and city similar to volunteering, giving residents a sense of civic engagement. Another consideration was the fee, determined by the amount of waste collected. These two factors provide residents with an indirect incentive to recycle, by encouraging them to sort their waste prior to collection, reducing the fee they paid. From the start of the scheme in 1994 to its end in 2000, this scheme was successful in changing citizen's behavior, resulting in a $30 \%$ reduction in waste per capita. The scheme also increased the amount of recyclable material collected, as well as increasing residents' sense of civic engagement, which is a strong contributor to enhancing well-being. This is in addition to the fact that people were aware they were helping the environment, as well as the actual physical benefit of achieving a more sustainable city. The role and responsibility of the various stakeholders are listed in Table 1 [9]. 
Table 1: Distribution of city waste-diminishing functions. (Source: Authors, 2021.)

\begin{tabular}{|l|l|}
\hline Entity & Role and responsibility \\
\hline Ministry of Environment & $\begin{array}{l}\text { To establish regulatory framework and develop strategies } \\
\text { and policies. } \\
\text { To provide technical and financial support to local } \\
\text { government. }\end{array}$ \\
\hline $\begin{array}{l}\text { Ministry of Trade, } \\
\text { Industry, and Energy }\end{array}$ & $\begin{array}{l}\text { To foster resource circulation industry. } \\
\text { To develop new and renewable energy. }\end{array}$ \\
\hline $\begin{array}{l}\text { Ministry of Land, } \\
\text { Infrastructure and } \\
\text { Transport }\end{array}$ & $\begin{array}{l}\text { To promote the use of recycled construction wastes. } \\
\text { To introduce quality certification system for recycled } \\
\text { aggregate. }\end{array}$ \\
\hline $\begin{array}{l}\text { Ministry of Oceans and } \\
\text { Fisheries }\end{array}$ & To manage ocean waste including marine plastics. \\
\hline $\begin{array}{l}\text { Ministry of Agriculture, } \\
\text { Food and Rural Affairs }\end{array}$ & $\begin{array}{l}\text { To manage compost and animal feed produced from } \\
\text { organic wastes to produce energy from biomass. }\end{array}$ \\
\hline $\begin{array}{l}\text { Province, Metropolitan } \\
\text { city }\end{array}$ & $\begin{array}{l}\text { To provide financial support to municipalities. } \\
\text { To coordinate projects among municipalities. }\end{array}$ \\
\hline City, County, District & $\begin{array}{l}\text { To collect and dispose of municipal waste. } \\
\text { To install and operate waste disposal facilities. }\end{array}$ \\
\hline Business, Developer & $\begin{array}{l}\text { To dispose of industrial waste. } \\
\text { To treat waste generating from development project. }\end{array}$ \\
\hline
\end{tabular}

\section{LIVING ENABLERS}

Though life in the city is influenced by many activities, there also exists the location and space itself as the physical substrate, plus the many other urban structures that enable living in the city. These structures take various forms, concepts and scales; such as green and blue spaces, housing, safety, infrastructure, urban planning and connectivity [7].

\section{HAPPINESS INDICATORS FOR GROSS NATIONAL HAPPINESS INDEX (GNH)}

The Global Happiness Index is a research-based indicator for measuring happiness in countries across the world. Happiness is shaped by a range of factors. The United Nations (UN) General Assembly adopted a resolution in 2011 imploring states to assess the happiness of their citizens in order to guide policy. The UN began its work on happiness and well-being in 2012, with the goal of building a clear economic structure to support it. Dubai formed the world's first Ministry of Happiness in 2016.

What elements affect to people's happiness? Individual and national wealth do not entirely define the global happiness standard; however, other indicators are highlighted in the classification method given in Table 2 [10].

\section{THE LONDON SUSTAINABLE DEVELOPMENT COMMISSION (LSDC)}

This commission was set up in 2002 to provide advice to the Mayor of London on ways to make the city more sustainable. An independent organization, it reaches policymakers in order to encourage a better lifestyle for all Londoners, now and in the future, while taking into consideration London's globalized impacts. The Commission is comprised of 
Table 2: Gross National Happiness Index (GNH) classification mechanism. (Source: Authors, 2021.)

\begin{tabular}{|c|c|c|c|c|c|c|}
\hline $\begin{array}{l}\text { Living } \\
\text { standards }\end{array}$ & $\begin{array}{l}\text { Ecological } \\
\text { diversity and } \\
\text { resilience }\end{array}$ & $\begin{array}{l}\text { Psychological } \\
\text { wellbeing }\end{array}$ & Health & $\begin{array}{l}\text { Time } \\
\text { use }\end{array}$ & $\begin{array}{l}\text { Community } \\
\text { vitality }\end{array}$ & Education \\
\hline Assets & $\begin{array}{l}\text { Ecological } \\
\text { issues }\end{array}$ & $\begin{array}{l}\text { Life } \\
\text { satisfaction }\end{array}$ & $\begin{array}{l}\text { Mental } \\
\text { health }\end{array}$ & \multirow{3}{*}{ Work } & $\begin{array}{l}\text { Donations } \\
\text { (time/money) }\end{array}$ & Literacy \\
\hline \multirow[t]{2}{*}{ Housing } & $\begin{array}{l}\text { Responsibility } \\
\text { towards the } \\
\text { environment }\end{array}$ & \multirow{2}{*}{$\begin{array}{l}\text { Positive } \\
\text { emotions }\end{array}$} & \multirow{2}{*}{$\begin{array}{l}\text { Self- } \\
\text { reported } \\
\text { health } \\
\text { status }\end{array}$} & & \multirow{2}{*}{$\begin{array}{l}\text { Community } \\
\text { relationships }\end{array}$} & \multirow[t]{2}{*}{ Schooling } \\
\hline & $\begin{array}{l}\text { Rural wildlife } \\
\text { damage }\end{array}$ & & & & & \\
\hline \multirow{2}{*}{$\begin{array}{l}\text { Household } \\
\text { per capita } \\
\text { income }\end{array}$} & \multirow{2}{*}{$\begin{array}{l}\text { Urbanization } \\
\text { issues }\end{array}$} & \multirow{2}{*}{$\begin{array}{l}\text { Negative } \\
\text { emotions, } \\
\text { spirituality }\end{array}$} & $\begin{array}{l}\text { Healthy } \\
\text { days }\end{array}$ & \multirow{2}{*}{ Sleep } & Family & Knowledge \\
\hline & & & Disability & & Safety & Value \\
\hline
\end{tabular}

Table 3: London Sustainable Development Commission (LSDC) indicators [11].

\begin{tabular}{|l|l|l|}
\hline Social indicators & Economic indicators & Environmental indicators \\
\hline - Education: Primary & - Gross value added & - Traffic volumes \\
- Education: Secondary & - Income inequality & - Air quality \\
- Childcare & - Employment rates & - Travel to school \\
- Crime & - Business survival & - Access to nature \\
- Decent housing & - Human capital & - Bird populations \\
- Life expectancy & - Innovation & - Ecological footprint \\
- Physical activity & - Child poverty & - Flooding \\
- Satisfaction with London & - Fuel poverty & - Household recycling \\
- Happiness & - Housing affordability & - Water consumption \\
- Voting & - London living wage & - Waste \\
- Volunteering & - Carbon efficiency & - Business/development \\
- Healthy life expectancy & - Low carbon and & recycling \\
- Social integration & environmental jobs & - NOx emissions \\
- Travel & - Skills & - $\mathrm{CO}_{2}$ emissions \\
\hline
\end{tabular}

individuals with expertise in London's economic, social, environmental, and governance sectors. The LSDC aims that the QOL measures will be useful to other Londoners. These indicators are supervised by the Mayor, cities, businesses, central government, and other private and public sector stakeholders all throughout London (Table 3) [11].

Hence, QOL indicators play an important role in the development of urban communities through the following stages. A proposal for indicators is illustrated in Fig. 8.

\section{CONCLUSIONS}

When discussing the concept of a Smart Happy City, people may consider technology to be a key component; however, in order to avoid an exclusive focus on technology, a broader and more inclusive scope is worth considering, in order to redefine smart cities. In this context, smarter means making better use of resources, methods and techniques, including high technology. The results of the analysis of the definitions and concepts of the Smart City suggest that there are three key issues: 


\begin{tabular}{|c|c|c|c|c|c|c|}
\hline \multicolumn{2}{|c|}{ Current status stage } & \multicolumn{2}{|c|}{ Vision phase } & \multicolumn{3}{|c|}{ The stage of achieving the vision } \\
\hline $\begin{array}{l}\text { Statistical } \\
\text { tools }\end{array}$ & $\begin{array}{l}\text { subjective } \\
\text { tools }\end{array}$ & $\begin{array}{l}\text { Clear } \\
\text { tools }\end{array}$ & $\begin{array}{l}\text { Tools for } \\
\text { comparison }\end{array}$ & $\begin{array}{l}\text { Tools for continuity } \\
\text { analysis, and monitori }\end{array}$ & & $\begin{array}{l}\text { Evaluation } \\
\text { tools }\end{array}$ \\
\hline $\begin{array}{l}\text { Understand the } \\
\text { current status } \\
\text { of the city as } \\
\text { one } \\
\text { comprehensive } \\
\text { unit }\end{array}$ & $\begin{array}{l}\text { Identify gaps } \\
\text { in the } \\
\text { different } \\
\text { sectors of the } \\
\text { city, and thus } \\
\text { identify the } \\
\text { needs for } \\
\text { development }\end{array}$ & $\begin{array}{l}\text { To express } \\
\text { goals and } \\
\text { priorities, } \\
\text { and then } \\
\text { prepare } \\
\text { urban } \\
\text { development } \\
\text { plans }\end{array}$ & $\begin{array}{l}\text { To compare } \\
\text { cities to } \\
\text { reach } \\
\text { urbanization } \\
\text { and } \\
\text { development } \\
\text { required }\end{array}$ & $\begin{array}{l}\text { To study the impact } \\
\text { of policies and } \\
\text { strategies in urban, } \\
\text { economic, social } \\
\text { and environmental } \\
\text { space }\end{array}$ & & $\begin{array}{l}\text { lusion } \\
\text { rate } \\
\text { marks } \\
\text { or progress in } \\
\text { ig structural } \\
\text { ems on a } \\
\text { ar and } \\
\text { ng basis }\end{array}$ \\
\hline
\end{tabular}

Figure 8: Proposed quality of life (QOL) indicators. (Source: Authors, 2021.)

1. Infrastructure is central to the Smart City concept. Technology is an enabling factor for smart cities, but it is not always the most critical factor. It is critical to combine, connect and maintain the integrity of systems and infrastructure in order to create a Smart City. The primary systems are not discrete and separate, but rather are transformed into a multifaceted system of connected systems in a synergistic manner that distributes better performance.

2. Processes (how a Smart City arises) play a key role in advancing definitions. A huge change in the way services are delivered is an important factor for a Smart City. A Smart City is primarily important for the development of services, rather than technology.

3. A vision for a better future is important. A Smart City must be able to forecast a smart economy, smart governance, smart mobility, a smart environment, smart people, smart living, and how they will interact. Yet having a vision for intelligent advancement is insufficient; actions in the fields of legislation, policy, and organizational change are required. On the other hand, infiltrating intelligence into each subsystem of a city is insufficient to create a Smart City; these dimensions must be considered as an organic whole. Our key point is that cities must be responsive to the context in which they operate, and what constitutes intelligence is dependent on a variety of contexts (texture and context), such as the political system, geographic conditions, and technology diffusion. Smart solutions, in fact, cannot be copied and must be valued from within different fields. Cities cannot easily copy good methods, but they must develop approaches that are appropriate to their conditions, because there are no two cities with the same conditions. For now, we can foresee that these factors and strategies will become reference tools to make Alexandria a Smart Happy city, as it will aim to design positive user experiences and set the city to shaping a Happy City policy through future planning and design for Alexandria.

\section{REFERENCES}

[1] Planetware. Tourist Attractions, Alexandria. https://www.planetware.com/touristattractions-/alexandria-egy-alex-alex.htm.

[2] Bosch, P. et al., CITYkeys indicators for smart city projects and smart cities, 2017. DOI: $10.13140 /$ RG.2.2.17148.23686. 
[3] Pourahmad, A., Ziari, K., Hataminejad, H. \& Pashabadi, S.P., Explanation of concept and features of a Smart City. Bagh-e Nazar, 15(58), pp. 5-26.

https://www.researchgate.net/publication/325417224_Explanation_of_Concept_and Features_of_a_Smart_City.

[4] Sustainable Development Goals Knowledge Platform, International Telecommunications Union, 2016. https://sustainabledevelopment.un.org/index.php? page $=$ view\&type $=30022 \& n r=231 \&$ menu $=3170$.

[5] Stubbs, P., Jan Gehl quotes. https://www.environmentshow.com/jan-gehl-quotes/.

[6] Bin Bishr, A., Happy cities in a Smart world. Smart Dubai Office: Dubai, UAE.

[7] The World Happiness Report 2020. https://worldhappiness.report/ed/2020/.

[8] Samad, W.A. \& Azar, E. (eds), Smart Cities in the Gulf: Current State, Opportunities, and Challenges. Gulf Research Centre: Cambridge.

https://www.digitaldubai.ae/docs/default-source/publications/smart-cities-in-thegulf_oct-2018.pdf?sfvrsn=c11343b5_0.

[9] South Korea's Experience with Smart Infrastructure Services: Integrated Solid Waste Management.

[10] Centre for Bhutan Studies and GNH Research, A compass towards a just and harmonious society: 2015 GNH survey report, Community Indicators Consortium, 2016.

https://communityindicators.net/resources/a-compass-towards-a-just-andharmonious-society-2015-g-nh-survey-report/.

[11] London's Quality of Life Indicators Report, 2017. https://londondatastoreupload.s3.amazonaws.com/QoL_2017_Summary_online.pdf. 